\title{
Uplifting A People: Essays on African-American Philanthropy and Education
}

\author{
Edited by Marybeth Gasman and Katherine V. Sedgwick, \\ Peter Lang Publishing, New York, NY, 2005; \\ ISBN: 0-820-47474-6; 216 pages; Price: \$29.95
}

International Journal of Educational Advancement (2007) 7, 71-73. doi:10.1057/palgrave.ijea.2150046

Before reading the book, Uplifting a People: African-American Philanthropy and Education, one may falsely assume that the focus will surround the reoccurring theme of success within the African-American community resulting from the benevolent actions of white, affluent individuals and/or organizations seeking to improve race relations. Nevertheless, the book highlights an overlooked trend within the philanthropic field-Black philanthropy.

Defined as "the giving of time, talent, goods, and money for charitable efforts," the subject of Black philanthropy represents a paradigmatic shift, as it focuses on the actions of African-Americans to uplift their own communities through modest acts of giving. Gasman and Sedgwick provide the reader with various perspectives that both scholars and students will find interesting, as the book allows the reader to embark upon a historical journey into understanding the role of agency during times of discrimination and oppression.
Comprised of 11 chapters, the book "illuminates the actions and lives of African-Americans who were philanthropic contributors and reviews the agency of Black people" (Gasman et al., 2005). In the introduction, the authors acknowledge their intent to explore the impact of AfricanAmerican philanthropy on "diverse educational institutions such as schools, colleges and universities, community centers, clubs, churches, the courts, and society as a whole" (Gasman et al., 2005). Thus, through its initial chapters, the book begins with an overview that presages the linkages between education and philanthropy within the Black community.

It is within the first two chapters that the authors provide their audiences with insight into the derivation and development of Black philanthropy. In response to slavery and segregation, Black philanthropic efforts became a means of ensuring survival through self-reliance and economic prosperity. For the reader 
who is knowledgeable about AfricanAmerican culture and history, there is nothing devastatingly new here by way of understanding that "whether free or enslaved, the goal of survival, liberation, and self-determination served as the forefront of black mutual aid" (Gasman et al., 2005).

Characterized by many as the formative years within Black philanthropy, the nineteenth century displayed churches, schools, and benevolent societies as central locations of Black philanthropic efforts. "Yet, there were some individual black philanthropists: those people who obtained wealth through inventions, professional artisans/artists, members of the Black intelligentsia, and business/plantation owners" (Gasman et al., 2005). Therefore, the remaining chapters highlight individual AfricanAmericans and the giving of their time, talent, and/or money to create opportunities for members of their community. For example, the chapters provide an excellent analysis on the contribution of both time and talent of individuals like Booker T. Washington and Thurgood Marshall, contributing to the ultimate fortification of the African-American community.

As one might expect in a book of essays that highlight the implications of Black philanthropy, the book is generally strong on its realistic connection to the customs and traditions of the African-American community, and reinforces this relationship through the welldocumented historical evidence. Nevertheless, it falls short on offering modern examples of Black philanthropy and contemporary suggestions on implementation. For instance, the chapter on Booker T.
Washington placed considerable attention on the philanthropic support he gained for the support of Tuskegee Institute, a historically Black university in Alabama founded by Washington. It would have been impressive if the authors discussed how Black colleges and universities might bridge this gap between philanthropy and education, in efforts to continue uplifting members of the African-American community in today's society.

Although the book lacks practical recommendations, it does not detract from the immense quality of the research, as the main strength of the book was the breadth of scholarship on which it relies for its analyses. Oftentimes, educational research separates into various domains; however, Gasman and Sedgwick are able to underscore the linkages between the separate essays, ultimately improving the coherence of the publication. Additional criticism on this book surrounds the "dated relevance" of the publication material, as many of the philanthropists illuminated are deceased, and the subjects of slavery and segregation are past, historical constructs. Black philanthropic actions must focus upon present issues within the Black community, such as inequality in education and workplace settings. Thus, a major concern focuses on the ability of younger audiences to connect and appreciate the span and scope of the research, due to the paradigmatic shift of societal concerns.

The linkages between education and economic prosperity are undeniable, especially in minority communities, and this book serves as a direct correlation between the aforementioned variables. Thus, 
providing insight into a new paradigm of agency-Black philanthropy.

Furthermore, it gives a glimpse of the early philanthropic activities among Black individuals, and the related outcomes that became precursors to the notion of uplifting the larger, African-American community. The book directly appeals to those interested in the conceptual framework of Black philanthropy, the emergence of the Black intellectual movement, the role of self-governed entities within the Black community, and those interested in the philanthropic deeds and accomplishments of Black intellectuals in overcoming the unique challenges of oppression and discrimination. Therefore, much discussion within this book should appeal to a broad range of readers: students, practitioners, scholars, foundations, nonprofit organizations, advancement professionals, civic/social organizations, and alumni associations.

Nevertheless, as the nation continues its commitment to increasing diverse interaction within all levels of society, it becomes important to build meaningful relationships. Throughout every chapter, Gasman and Sedgwick highlight the general theme of "interconnectedness," which allowed the African-American community to uplift one another through the donations of time, talent, goods, and money. Therefore, this book can serve as a diversity tool to reinforce the understanding of a community's "hidden culture," and its subsequent abilities to unite and overcome oppressed conditions.

Brandon L. Tilghman Peabody College of Vanderbilt University, 2418 Erin Lane, Nashville, TN 37221, USA 